\title{
Screening ciliopathy genes in the model organism Trypanosoma brucei
}

\author{
S Barry ${ }^{*}$ K Towers, S Vaughan \\ From First International Cilia in Development and Disease Scientific Conference (2012) \\ London, UK. 16-18 May 2012
}

We have carried out a bioinformatics study to search for novel proteins of the flagellum/cilium. A total of 26 candidate hypothetical genes were established from previously published studies including a flagellar proteome [1] and an RNAi study of motility mutants of Trypanosoma brucei [2]. All candidates are predicted to have orthologues in the human genome, the dysregulation of which is associated with or predicted to be involved in at least one ciliopathy. The protozoan parasite T. brucei is a well established experimental model to study defects in flagellum assembly and function. In this project we will confirm that the proteins from the candidate genes are localised to the flagellum or basal body by GFP-tagging. The function of each will be assessed using inducible RNAi methods and in future work will involve taking the work forward into human cell lines for some candidate genes to see if we can reproduce the same phenotype in the cilia of human cells.

Published: 16 November 2012

\section{References}

1. Broadhead $R$, Dawe $H R$, et al: Flagellar motility is required for the viability of the bloodstream trypanosome. Nature 2006, 440(7081):224-227.

2. Baron DM, Ralston KS, et al: Functional genomics in Trypanosoma brucei identifies evolutionarily conserved components of motile flagella. J Cell Sci 2007, 120(Pt 3):478-491.

\section{doi:10.1186/2046-2530-1-S1-P81}

Cite this article as: Barry et al:: Screening ciliopathy genes in the model organism Trypanosoma brucei. Cilia 2012 1(Suppl 1):P81.

\footnotetext{
* Correspondence: samantha.barry-2011@brookes.ac.uk
} Oxford Brookes University, UK

Submit your next manuscript to BioMed Central and take full advantage of:

- Convenient online submission

- Thorough peer review

- No space constraints or color figure charges

- Immediate publication on acceptance

- Inclusion in PubMed, CAS, Scopus and Google Scholar

- Research which is freely available for redistribution
() Bïomed Central 